\title{
PROGRAM OF RESEARCH AND EXPERIMENTAL STUDY OF FORMATION OF SOCIO-CULTURAL COMPETENCE OF FUTURE FOREIGN LANGUAGES ON THE BASIS OF INTERDISCIPLINARY APPROACH
}

\author{
Kateryna Fodor ${ }^{1}$ \\ ${ }^{I}$ English language teacher of Philology Department, Transcarpathian Hungarian Institute after Ferenc \\ Rákóczi II, Berehove, Ukraine, e-mail: fodor.katalin@kmf.org.ua, ORCID ID: http://orcid.org/0000-0002- \\ 5086-0944
}

\begin{abstract}
The article highlights the program of research and experimental investigation of formation of socio-cultural competence of future foreign languages on the basis of interdisciplinary approach. The logic of research and experimental work has been aimed at substantiating its stages, which reflect the achievement of intermediate goals through the use of certain forms and methods of organization: theoretical and methodological - 2017; diagnostic and constative - 2017-2018 academic year; formative - 2019 academic year; analytical and conclusion - 2020. Diagnostic and constative stage of research has been provided in two procedures: diagnostics of formation state of sociocultural competence of future foreign language teachers (diagnostic sub-stage) and entrance control of level of sociocultural competence of students before introduction of author's method. The outlined conception of the study has been realized within students of bachelor degree in the field of knowledge 01 "Education", specialty 014 Secondary Education (English language and foreign literature). The logic of organization of formative stage of research under consideretation presupposed implementation of methods of pedagogical conditions and structural-functional model of formation of socio-cultural competence of future foreign language teachers on the basis of interdisciplinary approach during year of study 2019 into the educational process of higher educational establishments that have been taken for the experiment.

In order to analyze the results of the formative stage of experimental study, numerical indicators of the formation of socio-cultural competence of future foreign language teachers at the stage of entrance and final controls have been compared. The certainty of results of experimental study has been proven with the help of the methods of mathematical statistics - comparison of variances for entrance and final control in control groups and experimental groups, determination of Fisher's criterion.
\end{abstract}

Keywords: competence, sociocultural competence, foreign language teachers, students, pedagogical conditions, methods.

JEL Classification: JEL I0; I20

Formulas: 0; fig.: 0, tabl.: 1; bibl.: 8

Introduction. Abstracting from specific features, we consider experimental research to be of twofold meaning. The first lies in testing of theoretical assumptions, calculations and conclusions. In this context, experimental researches are of significant importance. After all, any theoretical assumption that describes real phenomena is definitely incomplete and schematic. Since it includes the influence of a certain set of factors and circumstances that affect the process under investigation. In fact, the number of such factors and circumstances is enormously great, so only experimental study that examines the course of the phenomenon in existing reality can totaly prove the idea that those factors which in theory were not taken into consideration certainly have a rather little impact and respectively can be neglected if necessary. 
The second feature of experimental researches is reflected in the possibility of the experiment to investigate those phenomena (determining quantitative relations), which, at this level of science development, cannot be theoretically predicted and calculated.

Experimental work of the present scientific research is aimed at experimental testing of the effectiveness of pedagogical conditions as well as structural and functional model of socio-cultural competence of future foreign language teachers on the basis of interdisciplinary approach. From this respect, scientific experiment has been organized in higher educational establishments without breaking a natural logic of the educational process and at the same time served as the mechanism for testing the investigated factors.

Literature Review. Paradoxically, however, the notion «experiment», has a great number of various definitions. The article under consideration gives the analysis of some definitions, aimed at building your own version of the interpretation of the content of this category, which accumulates the essential features of the definitions used by modern authors and declares the organizational aspects of the researcher in pedagogical experiment.

In the context of philosophical study the experiment is defined as «observation which is systematically carried out; systematical isolation, combination and variation of conditions aimed at investigating the modification peculiarities of subordinate phenomena» $[8, \mathrm{p} .156]$. At the same time, a scientist provides the possibility for observation, on the basis of which his/her awareness about the development regularities of phenomenon is being built up. Thus, we believe that observations, conditions, knowledge, regularities- are the most important features that characterize the proposed definition.

Contrastly, O. Kasatkina [6], highlighting psychological and pedagogical elements of the development of communicative competence of students (on the example of learning English), states that the notion "experiment", is considered in modern psychological science as one of the basic methods of scientific cognition in general (alongside with observation), and psychological research in particular. The author notes that "experiment differs from observation by active intervention into the situation by the researcher, who systematically manipulates one or more variables (changeable factors) and registers changes in the development of the object under investigation " [6, p. 13].

Investigating the application specifics of the category "experiment" in pedagogical practice, O. Josan [3] distinguishes the plurality of meanings being used. The methodologist notes that all of them, "are equivalents (equal), since any of them can be taken from the others, and each of them explains this or that side of the investigated phenomenon" [3, p. 14]. In our opinion, this point of view is not always legitimate, since it is extremely difficult to reproduce the integrity of multidimensional object of a particular pedagogical phenomenon with only one variable element of the development, though even the most significant, but onedimensional. According to O. Josan [3] experiment is a research method which presupposes identification of some significant factors that affect the results of 
teaching activity, and methodological principles that allow to vary these factors in order to achieve optimal research results [3, p. 15].

We suppose it important to provide some other existing definitions of the term under consideration for representing integral version of its interpretation, which includes the completeness of the essential features of the experiment:

-scientifically substantiated experience (N. Bilotserkivska [1, c. 99]);

-hypothesis testing (O. Zagoruyko [4]); reproduction of a technique developed by one teacher (technology, system, etc.) in new conditions by another teacher or manager (M. Bratko [2, p.8]);

-method of cognition, by means of which pedagogical phenomenon is being investigated under natural or artificial, controlled conditions, new way of problem is being searched out (I. Zakiryanova [5, p. 122]);

-strictly directed and controlled teaching activity towards development and approbation of new technologies in education, development of students, high school administration (T. Kolodko [7, p. 92]).

Taking into consideration all essential features of definitions mentioned above, it seems possible to provide the following definition of "experiment" in our scientific work: research activity which has been organized for testing pedagogical conditions and developed structural and functional model of formation of socio-cultural competence of future foreign language teachers on the basis of interdisciplinary approach, taking place in natural and controlled conditions of educational process in higher educational establishments of Ukraine. This activity results in new idea about the process of formation of structural components of sociocultural competence.

Aims. The purpose of the article is to highlight the program of research and experimental study of formation of socio-cultural competence of future foreign language teachers on the basis of interdisciplinary approach.

Methods. The following methods of investigation have been applied for fulfillment of the set objective: theoretical: analysis of pedagogical, educationalmethodical, normative literature and scientific works on the topic of the article, subject and logical, information-oriented analysis of text materials; empirical. Thus, a wide range of diagnostic techniques have been applied to identify the current state of formation of motivational and axiological components of sociocultural competence of future foreign language teachers, namely: replication of "Value Orientations" (by M. Rokeach), diagnostic method of academic motivation of students (by A. Rean, V. Yakunin), test that determines the level of motivation of an individual to sociocultural activity (adapted by the author according to the method of N. Bilotserkivska).

Guilford's Test "Social intelligence" has been applied in order to reveal the current state of formation of linguistic component of socio-cultural competence of future foreign language teachers, as well as a complex of various tasks for diagnostics of development of special professional (vocabulary, grammar, phonetics) which reflect peculiarities of language picture of the world of a definite culture.

In the context of communicative, acitivity-oriented component of sociocultural competence of future foreign language teachers a special questionnaire has been applied for diagnostics of the level of development of communicative skills of the 
future foreign language teachers and diagnostics of behavior of an individual in conflict situation. In order to identify the state of formation of culturological component of socio-cultural competence of future foreign language teachers express questionnaire "Tolerance Index" as well as a method for determination of the level of socio-cultural identity have been used.

Results. Taking into consideration the information mentioned above it is necessary to touch upon the logic of experiment conductin; stages and structural components of the experimental cycle. It has been taken into account that the effectiveness of experimental activity is determined by the sequence of main stages maintained by the researcher. Therefore, focusing on the logic of the experimental cycle, some of its stages have been carefully ellaborated.

In accordance with investigation tasks, the logic of research and experimental work has been aimed at substantiating its stages, which reflect the achievement of intermediate goals through the use of definite forms and methods of organization: theoretical and methodological - 2017; diagnosic and constative - 2017-2018; formative- 2019; analytical and conclusive - 2020 (Pic. 3.1.).

All the stages mentioned above will be further characterized.

Theoretical -methodological research stage has been being conducted since 2017 and resulted in the following:

- the urgency of the problem of formation of socio-cultural competence of future foreign language teachers on the basis of interdisciplinary approach has been revealed;

- the purpose, object, subject, tasks of research work have been specified;

- a wide range of contradictions which prevent problem solution of formation sociocultural competence of future foreign language teachers based on the analysis of the current state of development of society, the needs of educational practice for a teacher of a foreign language in general secondary educational establishments, who is able to carry out professional activity in a multicultural environment by means of retransmission of native culture values;

- socio-cultural preconditions of modernization of professional training of future foreign language teachers in terms of renovation of pedagogical education have been characterized;

- didactic potential of the interdisciplinary approach in the formation of sociocultural competence of future foreign language teachers has been outlined;

a number of methodological approaches (competence, culturological, systemic, axiological, activity, acmeological, multicultural) have been singled out, realization of which enables the implementation of these ideas into the process of professional training of foreign language teachers;

- the experimental base of research has been determined (higher educational establishment and disciplines which actualize the possibilities of formation of sociocultural competence of future foreign language teachers by using fundamental principles of interdisciplinary approach).

Diagnostic and constative (2017-2018 academic year) stage of research and experimental research involved two procedures: diagnosis of formation state of 
socio-cultural competence of future foreign language teachers (diagnostic sub-stage) and inner control of the level of socio-cultural competence of students before the introduction of the author's method (constative sub-stage); and was marked by the implementation of the following:

- components, criteria, indicators and levels of socio-cultural competence of future foreign language teachers have been specified;

- set of diagnostic techniques that determine formation level of components of socio-cultural competence of future foreign language teachers have been systemized;

- pedagogical conditions have been singled out and theoretically substantiated, structural-functional model of formation of socio-cultural competence of future foreign language teachers on the basis of interdisciplinary approach have been designed;

- constative sub-stage of the experiment has been carried out, on the basis of its results the need for purposeful application of ideas of interdisciplinary approach has been revealed in order to form socio-cultural competence of students of this specialty.

The outlined brunch of the study has been carried out within students of bachelor degree, the field of knowledge 01 "Education" in specialty 014 Secondary Education (English language and foreign literature). At the time of the diagnostic activities, teachers-to-be have completed the fourth year of study. Diagnosis of formation of socio-cultural competence of students of this specialty was carried out at the last lesson( disciplines "Practice of oral and written translation").

Discussion. In order to fulfill the objective tasks of research, the author's decision was made to organize a constative sub-stage of pedagogical investigation on the basis of diagnosis of future foreign language teachers. The predominant purpose of this stage was to establish the current level of formation of socio-cultural competence of future teachers of this specialty. Therefore, diagnostic procedures involved students from: Uzhhorod National University, Mukachevo State University, Drohobych State Pedagogical University of Ivan Franko, Rivne State Humanitarian University.

Generally, 110 students have been involved into constative sub-stage of research. Quantitative distribution of participants in the diagnosis is represented in Table 1.

Table 1. Number of future foreign language teachers having participated in research at diagnostic-constative stage

\begin{tabular}{|l|c|}
\hline \multicolumn{1}{|c|}{ Higher educational establishment } & $\begin{array}{c}\text { The number of } \\
\text { students }\end{array}$ \\
\hline 1. Uzhhorod National University & 25 \\
\hline 2. Mukachevo State University & 30 \\
\hline 3. Drohobych State Pedagogical University of Ivan Franko & 35 \\
\hline 4. Rivne State Humanitarian University & 20 \\
\hline Total number & 110 \\
\hline
\end{tabular}

In an attempt to perform mathematical and statistical calculations and hence to simplify the procedure of their consolidation into a single systemic integrity of 
diagnostic data at all stages of experiment a 5-point scale has been used. In the process of diagnosis of the level of formation of socio-cultural competence different levels of development of socio-cultural knowledge about other linguistic communities, skills to establish communicative pedagogical interaction with students, ability to retransmit the heritage of native culture, skills of socio-cultural tolerance. However, unsatisfactory level of development of investigated competence of students has not been diagnosed. Therefore, four descriptive scales of formation of sociocultural competence were used. Under such conditions, numerical indicators from 5 to 2 reflected the content of distinguished levels of the announced phenomenon. Research idea is presented in the following way:

-5 points -high level;

-4 points - sufficient level

-3 points - satisfactory level;

-2 points - low level.

Alongside, average indicator has been calculated, preconditioned by the need of its application in further mathematical calculations. The position of I. Zakiryanova [5] has bbeen appealed to in this respect. The researcher emphasizes the expediency of using this indicator describing the plane of diagnostic stage of detecting the dynamics of socio-cultural competence of future teachers, [5, p. 185].

It is worth being mentioned that during the entry and final control at the formative stage of the author's experimental study a similar package of diagnostic materials has been used. This made it possible to ensure the same entrance conditions of future foreign language teachers who studied in different educational establishments, the same conditions for admission to research and experimental work

At the diagnosis and constative stage of experiment it has been established, that formation of socio-cultural competence of future foreign language teachers indicates the need to improve the training of students in this specialty. Analysis of total indicators of formation of socio-cultural competence of future foreign language teachers enabled to conclude: only $27.27 \%$ of students demonstrated high level, $39.09 \%$ - sufficient level, 32.3\% - satisfactory level, $0.91 \%$ - low level of competence; average indicator was 3.93 points.

Investigation of obtained results of diagnostic and constative stage of research proved the hypothesis about the necessity of implementation of interdisciplinary approach into the process of professional training of future foreign language teachers for the formation of socio-cultural competence.

Announced information confirms the topicality of our study and leads to the use of socio-cultural potential of the disciplines of the humanities cycle, socio-economic, nature, scientific, professional and practical training of future foreign language teachers by using methodological basis of interdisciplinary approach. At the same time, we consider general results of the diagnostic and constative stage of the experimental research as guiding vectors for planning, ellaboration and implementation of organizational actions of the formative stage of formation of socio-cultural competence of future foreign language teachers on the basis of interdisciplinary approach. 
The logic of organization of formative stage of the present research presupposed realization of implementation methods of pedagogical conditions and structuralfunctional model of formation socio-cultural competence of future foreign language teachers on the basis of interdisciplinary approach during 2019 year into the educational process of higher educational establishments that have been taken for the experiment. Implementation of experiment in this stage made it possible:

- to design unified integrated socio-cultural field / environment of professional training of future foreign language teachers in the educational process of higher educational establishments on the basis of interdisciplinary approach;

-to systematize the means of interdisciplinary approach in the methods of formation of socio-cultural competence of future foreign language teachers;

- to develop and to test experimental method of realization of pedagogical conditions and structural-functional model of formation of investigated competence of future foreign language teachers on the basis of interdisciplinary approach;

-on the basis of implementation of methods of expert assessment, pedagogical observation, interview, survey, questionnaire, the problem areas of the author's structural and functional model have been identified and appropriate adjustments have been made to the methodological support of its implementation.

To summarize the analysis of the results of scientific research, analytical and final stage has been organized (in 2020), during which the following steps were taken:

- the results of the formative stage of research and experimental work have been systematized; the content of theoretical and methodological issues of formation of socio-cultural competence of future foreign language teachers in terms of modernization of pedagogical education have been specified;

- obtained research results are represented in the text of dissertation and in educational and methodological works of the author;

-experimental testing of the effectiveness of implementation of pedagogical conditions and structural-functional model has been carried out; their effectiveness was proven applying the methods of mathematical statistics;

- basic results of research of the formation of socio-cultural competence of future foreign language teachers on the basis of interdisciplinary approach into educational practice of higher educational establishments of Ukraine, which is confirmed by implementation certificates.

The logic of achieving the objectives of research leads to highlighting of the essence and features of the methodological implementation of pedagogical conditions as well as structural and functional model of the formation of socio-cultural competence of future foreign language teachers on the basis of interdisciplinary approach.

Conclusions. The logic of research and experimental work was aimed at substantiating its stages, which reflect the achievement of intermediate goals through the use of certain forms and methods of organization: theoretical and methodological - (2017); diagnostic and constative - (2017-2018 academic year); formative - (2019 academic year); analytical and conclusion - (2020). Diagnostic and constative stage 
of research provided carrying out of two procedures: diagnostics of a state of formation of socio-cultural competence of future foreign language teacher (diagnostic sub-stage) and entranrance control of level of socio-cultural competence of students before implementation of author's technique (constative sub-stage). The outlined brunch of research has been conducted within students of bachelor degree, the field of knowledge 01 "Education" in specialty 014 Secondary Education (English language and foreign literature). At the time of the diagnostic activities, teachers-tobe have completed the fourth year of study. Diagnosis of formation of socio-cultural competence of students of this specialty was carried out at the last lesson( disciplines "Practice of oral and written translation").

Analysis of obtained results of diagnostic and constative stage of research proved the hypothesis about the necessity of implementation of interdisciplinary approach into the process of professional training of future foreign language teachers for the formation of socio-cultural competence. The logic of organization of formative stage of research under consideration presupposed implementation of methods of pedagogical conditions and structural-functional model of formation of socio-cultural competence of future foreign language teachers on the basis of interdisciplinary approach during year of study 2019 into the educational process of higher educational establishments that have been taken for the experiment.

In order to analyze the results of the formative stage of experimental study, numerical indicators of the formation of socio-cultural competence of future foreign language teachers at the stage of entry and final control have been compared. The certainty of results of experimental study has been proven with the help of the methods of mathematical statistics - comparison of variances for entrance and final control in control groups and experimental groups, determination of Fisher's criterion.

However, carried out research does not cover all aspects of the problem of forming socio-cultural competence of future foreign language teachers on the basis of interdisciplinary approach. Prospects for further researches are related with improving disciplinary structure of academic curriculum for bachelors in the field of knowledge 01 "Education", specialty 014 Secondary Education (English language and foreign literature) in order to ensure interdisciplinary and intradisciplinary connections among disciplines; systematization of forms, means, methods of organization of educational activity of students of this specialty in the development of skills of socially tolerant intercultural pedagogical communication.

\section{References:}

1. Bilotserkivska N. H. Formuvannya sotsiokulturnoyi kompetentnosti maybutnikh uchyteliv u protsesi vyvchennya humanitarnykh dystsyplin[Formation of socio-cultural competence of future teachers in the process of studying the humanities]: dys. ... kand. ped. nauk: 13.00.04 / Khark. nats. ped. un-t im. H. S. Skovorody. Kharkiv, 2009. 198 s.

2. Bratko M. V. Osvitnye seredovyshche vyshchoho navchalnoho zakladu: funktsionalnyy aspect [Educational environment of higher education: functional aspect]. Pedahohichnyy protses: teoriya i praktyka. 2015. Vyp. 1-2. S. 11-18.

3. Zhosan O. E. Pedahohichnyy eksperyment: navch.-metod. Posib[Pedagogical experiment: teaching manual]. Kirovohrad: Vyd-vo KOIPPO im.i V. Sukhomlynskoho, 2008. 72 s.

4. Zakiryanova I. A. Dynamika sotsiokulturnoyi kompetentnosti maybutnikh pedahohiv [Dynamics of sociocultural competence of future teachers]. Teoretychni pytannya kultury, osvity ta vykhovannya : zb. nauk. pr. K. : Vyd. tsentr KDLU, 2002. Vyp. 21. S. 183-189. 
5. Zakiryanova I. A. Formuvannya sotsiokulturnoyi kompetentnosti u maybutnikh uchyteliv inozemnoyi movy $\mathrm{v}$ protsesi profesiynoyi pidhotovky [Formation of socio-cultural competence in future teachers of a foreign language in the process of professional training]: avtoref. dys. na zdobuttya nauk. stupenya kand. ped. nauk : spets. 13.00.04. Kyyiv, 2006. $23 \mathrm{~s}$.

6. Kasatkina O. V. Psykholoho-pedahohichni osnovy rozvytku komunikatyvnoyi kompetentnosti studentiv (na prykladi vyvchennya anhliyskoyi movy) [Psychological and pedagogical bases of development of communicative competence of students (on an example of studying of English language)]: avtoref. dys... kand. psykhol. nauk: 19.00.07. Ivano -Frankivsk, 2007. $20 \mathrm{~s}$.

7. Kolodko T. M. Formuvannya sotsiokulturnoyi kompetentsiyi maybutnikh uchyteliv inozemnykh mov u vyshchykh pedahohichnykh navchalnykh zakladakh [Formation of socio-cultural competence of future teachers of foreign languages in higher pedagogical educational institutions]: avtoref. dys... kand. ped. nauk: 13.00.04. Kyyiv. 2005. $220 \mathrm{~s}$.

8. Filosofskyy entsyklopedycheskyy slovar [Philosophical encyclopedic dictionary]. Moskva: YNFRA, 2001. $576 \mathrm{~s}$. 